\title{
Gáldy, Andrea M.
}

\section{The Art, History and Architecture of Florentine Churches.}

Newcastle upon Tyne: Cambridge Scholars Publishing, 2016. Pp. xxix, $458+64$ ill. ISBN 978-1-4438-9754-9 (hardcover) $£ 63.89$.

This pocket-sized book has the feel of a manual, and indeed Andrea Gáldy's purpose is to supply a handy reference in English to the twenty-five most important churches in Florence. The intended audiences for the book are English-speaking students and enlightened tourists; a useful multi-language glossary of terms related to architecture precedes the main text. (One small quibble: the entry for "basilica" is rightly separate from that for Latin-cross plan church, but as the term "basilica-plan" is sometimes used, it might be further explained and contrasted with Greek-plan and centrally-planned churches.) The glossary is followed by a short introduction to Renaissance Florence and a list of opening times and other practical information. Each church has its own chapter; the first two chapters are very long ones on the baptistery and the cathedral complex. The selection of the churches is exemplary and corresponds to what tourists and students are most likely to see; I would only plump for adding Sant' Egidio, in the next edition, so we can read about Lorenzo Monaco's exquisite Adoration of the Magi (now in the Uffizi). The included churches range from the most obvious-Santa Maria Novella, Santa Croce, San Marco, San Lorenzo-to the more niche, like San Remigio and the Badia Fiorentina. Each section begins with a short introduction to the church, its foundation, and key moments in its history. This is followed with a review of its architecture and highlights of the art displayed within. Every section has a photo of the church with its groundplan. Then commences the unique feature of the book: primary sources for the architecture and art in each church are quoted in English translation, following the chronological order of their publication. Hence, for the Cathedral of Santa Maria del Fiore, the section begins with Giovanni Villani's early fourteenthcentury chronicle, with what appears to be the first mention of the early church underlying the Duomo, Santa Reparata. Villani is also the first reference in the section on San Lorenzo, but here one could ask why the earliest sources about the foundation of San Lorenzo were not presented (for example, in a life of St. Ambrose by his secretary). However, Gáldy's sources (as laid out in xxviii-xxix) are confined to classic art-historical compendia of art, artists, and churches, 
plus Dante and Jacob Burckhardt's The Civilization of the Renaissance in Italy. Some of the selected sources are available in English or in digital format.

Gáldy has read each source thoroughly and captured any mention of the church in question. In some cases this is simply a single reference to the church, while in other cases, such as Vasari's monumental Lives of the Most Eminent Painters, Sculptors and Architects, there can be dozens of sub-entries, each one taken from a specific artist's biography. For instance, for the church of Santa Croce the Vasari section has thirty-eight entries, arranged under the names of artists from Cimabue, Giotto, Ghiberti, and Donatello to Vasari himself. Entries include not only works of art but also any mention of the name of the artist, as in the case of Ghiberti, whose burial in Santa Croce is recorded by Vasari, and hence in this text. After Vasari, the next source is almost always Francesco Bocchi's The Beauties of the City of Florence. The author transcribes every mention of the church in the order in which it occurs in Bocchi. Since Bocchi's organizational principle is to walk around the church, the order in which artists or works of art come up is quite different from that in Vasari (whose material is organized according to the artificer). This means that the reader cannot easily scan each church's holdings by a specific work of art, or an artist's name, unless that work or artist is mentioned in the author's introductory portion to each chapter (only items in the introductions are in the Index). Still, there are some rare pleasures to be had by reading sequentially through a church to realize what was originally there. Previously, only relatively inaccessible and cumbersome texts for specialists-Walter and Elisabeth Paatz's magisterial Die Kirchen von Florenz being prime among them-could allow a diligent student to realize what has been removed, destroyed, or lost from the churches in Florence. Thus, one can imagine Donatello's four saints, each tenfeet tall and made from stucco, set up on the moulding of the transept in San Lorenzo. What saints were they? And what message did they convey as they looked down at the congregation? As is befitting a book aimed at the general reader, the bibliography is trim, mainly focusing on larger studies rather than on the specific studies and journal articles. Lastly, size matters: this is definitely a book one can carry around on planes and in luggage.

ELIZABETH PILLIOD

Rutgers University - Camden 